


\section{Genocide Studies and Prevention 5:2}

Special Section: Genocide in Latin America

Daniel Feierstein and Henry Theriault

Editors'Introduction

Walter Delrio, Diana Lenton, Marcelo Musante, Mariano Nagy, Alexis Papazian, and Pilar Pérez

Discussing Indigenous Genocide in Argentina: Past, Present, and

Consequences of Argentinean State Policies toward Native Peoples

Mario Ranalletti

Denial of the Reality of State Terrorism in Argentina as Narrative of the Recent Past: A New Case of "Negationism"?

Santiago Garaño

The Opposition Front against Conupulsory Military Service: The Conscription

Debate and Human-Rights Activism in Post-Dictatorship Argentina

The Security Council Debates Rwanda: An Insider's Account

Herb Hirsch

Editor's Introduction

Karel Kovanda

The Czech Republic on the UN Security Council: The Rwandan Genocide

Book Reviews

Chris Hedges, Empire of Illusion: The End of Literacy and the Triumph of Spectacle reviewed by Herb Hirsch

Hrayr S. Karagueuzian and Yair Auron, A Perfect Injustice: Genocide and Theft of Armenian Wealth reviewed by Uğur Ưmit Üngör

Kim S. Theriault, Rethinking Arshile Gorky reviewed by Sara Cohan

Contributors 


\title{
Discussing Indigenous Genocide in Argentina: Past, Present, and Consequences of Argentinean State Policies toward Native Peoples
}

\author{
Walter Delrio \\ CONICET and Universidad de Río Negro
}

Diana Lenton

CONICET and Universidad Nacional de Buenos Aires

Marcelo Musante

Universidad John Kennedy and Universidad Nacional de Buenos Aires

Mariano Nagy

Universidad Nacional de Buenos Aires

\section{Alexis Papazian \\ CONICET and Universidad Nacional de Buenos Aires}

\section{Pilar Pérez \\ CONICET and Universidad de Río Negro}

For a long time the historiographical and anthropological narrative in Argentina contributed to a double assumption that is nowadays strongly grounded in citizens' common sense. On the one hand, the extinction of Indigenous peoples is vaguely dated to a period from the Spanish conquest to the military campaigns known as the "conquest of the desert"; on the other hand, such extinction is simultaneously interpreted as a "natural" process in universal history. Argentine state policies were thus naturalized. It is frequently assumed that this set of natural processes might have left only individual "descendants," in place of political entities. Therefore, modern Argentine society would be the outcome of a European "melting pot" in which the Indigenous component is absent. We postulate that physical elimination, concentration practices, deportation, enslavement, identity cleansing of children, and cultural destruction constitute mechanisms of honiogenization that add up to conceptualizing policies toward Indigenous peoples in Argentina as genocide. Ethnic politics following the military campaigns were based on the assumption of the near-"extinction" of those peoples. Federal and provincial governments constructed their policies on the basis of considering Indigenous peoples as "survivors," "the final remains of an ending culture," "ihe few left," and so on, omitting to name the causes of that supposed extinction. Our focus in this article is on current cultural policies that announce intercultural, plurality, and diversity goals while at the same time aiming to limit the margins of Indian political autonomy. We propose that this genocidal project is linked inextricably to the constitution and organization of the Argentine national state.

Key words: genocide, Argentina, Indigenous peoples, state policies, conquest of the desert

Walter Delrio, Diana Lenton, Marcelo Musante, Mariano Nagy, Alexis Papazian, and Pilar Pérez, "Discussing Indigenous Genocide in Argentina: Past, Present, and Consequences of Argentinean State Policies Toward Native Peoples." Genocide Studies and Prevention 5, 2 (August 2010): 138-159. (C) 2010 Genocide Studies and Prevention. doi:10.3138/gsp.5.2.138 
For a long time the historiogxaphical and anthropological narrative in Argentina contributed to state a double assumption that is nowadays strongly grounded in citizens' common sense. On the one hand, the extinction of Indigenous peoples over a period of time is vaguely dated from the Spanish conquest (mid-sixteenth century) to the military campaigns known as "Conquest of the Desert" (1878-1885). On the other hand, such extinction is simultaneously interpreted as a "natural" process in universal history, considering civilization's forward movement over "less civilized" societies. Argentine state policies were thus naturalized. It is frequently assumed that this set of natural processes might have left only single "descendants," in place of political entities. Therefore, modern Argentine society is said to be the outcome of a European "melting pot," in which the Indigenous component is absent.

The political and cultural homogeneity of the country constituted a political goal for the governing class in the nineteenth century. Although Indigenous peoples were not the only focus, the policies implemented with respect to them are paradigmatic and exhibit this trend categorically. In Part 1 below we analyze the military campaigns of 1878-1885, which ended with Indigenous political autonomy, postulating that physical elimination, concentration practices, deportation, enslavement, identity cleansing of children, and cultural destruction constitute mechanisms that add up to conceptualizing this political process as genocide.

The ethnic politics produced by the military occupation were based on the assumption - widely spread in citizens' "common sense" through Argentina's educational policies-of the near-"extinction" of Indigenous peoples. As will be developed in Part 2 below, both federal and provincial governments constructed their policies from a conceptualization of Indigenous peoples as "a few survivors," "the final remains of an ending culture," and so on. On the one hand, this omitted naming the causes of this supposed extinction. On the other hand, these policies of invisibilization enabled various forms of repression such as land expropriations, potential forced labor, and, at the same time, massacres like those at Napalpí (1924) and La Bomba (1947).

An analysis of the constitution of a now public arena of debate on Indigenous genocide is addressed in Part 3. In this debate, the Indigenous peoples' agency challenges the limits of recognition and re-emergence by making visible the genocidal social practices of the past and their symbolic realization through time. Furthermore, these groups denounce not only the original intent of extermination but also the mechanisms of enslavement and expropriation that followed military subjection. The focus is on current cultural policies that announce intercultural, pluralist, and diversity-related goals while at the same time aiming to limit the margins of Indigenous political autonomy.

The genocidal project is inextricably linked to the constitution and organization of the Argentinean national state and to its expansion of land jurisdiction over Indigenous territory by the late nineteenth century. In fact, the military campaigns of occupation on the southern frontier (Pampa and Patagonia, 1878-1885) and on the northern one (Chaco, 1884-1917) ${ }^{1}$ were executed with certain continuity of criteria, agencies, and actors. In addition, the realization of these campaigns boosted the political careers of persons and groups and eventually shaped the state's organization. In this way, later Argentineans inherited a state and a society built upon an elimination objective that was aimed, in particular, against the cultural "Other," and as a result the survivors of this genocidal project could be incorporated as a labor force. 


\section{Argentina's Indigenous Policies as Genocide}

The collective research project on which the authors of this article have been working ${ }^{2}$ aims to rebuild the historical process of subjugation and incorporation of Indigenous peoples into the Argentine state. Entangled in the same public debate that we discuss in Part 3, we were pushed to acknowledge the existence of an original intent of elimination that has enabled further normalization policies aimed at the Indigenous peoples of Argentina. This led us to frame the description of the process within a conceptual field that enables us to define it as a genocidal project. Therefore, we decided to read the process through the definition of genocide proclaimed in the UN Convention on the Prevention and Pumshment of the Crime of Genocide (UNCG) of $1948 .^{3}$

According to the UNCG, "genocide" means

any of the following acts committed with intent to destroy, in whole or in part, a national, ethnical, racial or religious group, as such:

(a) Killing members of the group;

(b) Causing serious bodily or mental harna to members of the group;

(c) Deliberately inflicting on the group conditions of life calculated to briug about its physical destruction in whole or in part;

(d) Insposing measures intended to prevent births within the group;

(e) Forcibly transferring children of the group to another group. ${ }^{4}$

The sections that follow analyze various facts-and their genocide intent-in the process of the "Conquest of the Desert" as a recurrent pattern in Argentine state policies toward Indigenous peoples between 1878 and 1885 .

\section{(a) Killing Members of the Group}

"Not a single Indian crosses the Pampas where many tribes used to live."5 With these words General Julio A. Roca, by then president of Argentina, highlighted genocide as one of his admimistration's achievements. As on other occasions, the republic's policies toward Indigenous peoples showed a violent and exterminatory side, related to the aim of emptying strategic territories and replacing the Native population with a European one. Although the national heroes of the War of Independence at the beginning of the mineteenth century had referred to Indigenous peoples as "brothers" or "fellow citizens," these feelings of unity and empathy began to turn, by the late nineteenth century, into expressions of condemnation for their genealogical imperfection and effective policies of land expropriation. Some of the most important theorists of the republic expressed their desire to eliminate the Native population. The "Conquest of the Desert" (Pampa and Patagonia, 18781885) and "Campaigns to the Green Desert" (Chaco, 1884-1917) extended through time as a permanent state of war of varying intensity. During these campaigns, the killing of Indigenous people on the "battlefield" or their extermination was a constant possibility as a consequence of the "state of exception" 6 that enabled the armed forces to execute prisoners and families in the name of the "rights of civilization."7 We will go over some cases below.

An example is the slaughter known as "Pozo del Cuadril." In November 1878, in a frontier expansion encouraged by the cattle breeders of the Pampa area, a group belonging to the Ranquel people approached the city of Villa Mercedes, with which they had early social and economic bonds. This group approached to collect their "rations," the outcome of a peace treaty signed with the federal government three months earlier. These "rations" were the compensation negotiated with the state 
for the reduction in sheep-herding, hunting, and agricultural land for the tribes. Nonetheless, Colonel Rudecindo Roca, military commander of Rio Cuarto (near Villa Mercedes), betrayed and attacked them, taking many of them prisoner. At least sixty male prisoners were shot dead in a barnyard; the women and children were sent to Tucumán as forced laborers. This incident was reported and debated in the press, especially in El Pueblo Libre (Córdoba) and La Nación (Buenos Aires), whose editors qualified it as a "crime against humanity." an isolated event and that impunity for such crimes could become a normal and extended practice during the coming military campaigns. La Nación then predicted that victims would not be only the Indigenous warriors but also elders, women, and children.

La Nacion's warnings anticipated facts that have been retold within Indigenous narratives across communities in Pampa and Patagomia since the campaigns began. The late Catalina Antilef, a Futahuao resident of Chubut province, remembered her grandmother's life experiences:

Oh, how should I tell you ... My granny used to say that they escaped from the war, poor thing, she used to cry, she used to mourn when she remembered ... they were taken to a place where they killed them all, they were from different places, [and] those who escaped came here. May God keep us from living that again. ${ }^{9}$

Such killings, described through collective memory, have frequently appeared in official records as the outcome of ordinary combat. An example is the "battle of Apeleg," which in fact consisted of a sudden and outrageous attack against an Indigenous camp at sunrise. On February 1883, Commander Nicolás Palacios attacked Chief Inacayal's camp; only two soldiers were killed on the battlefield, ${ }^{10}$ while more than 100 Indigenous people, among them women and children, were murdered. The survivors were first marched more than $1,200 \mathrm{~km}$ and concentrated in Valcheta, then later deported to Buenos Aires.

\section{(b) Causing Serious Bodily or Mental Harm to Members of the Group}

When the military campaigns in Pampa and Patagonia ended (by 1885), all the Indigenous survivors were concentrated under military control. Regardless of whether they had surrendered spontaneously or continued fighting against the army, after their defeat they were enclosed and deprived of access to their former resources.

For adult men, the army was their first destination and probably their last. They were known as "Indigenous auxiliary troops" or "squadrons of Indian friends." Although these divisions had existed since the colonial period, they grew notoriously during the $1880 \mathrm{~s}$, when desertion by criollo ${ }^{11}$ soldiers increased.

In various communities of Pampa and Patagonia, narratives of the "grandparents' times" talk about material and non-material losses (possessions, persons, sacred places, peace, etc.) as well as about displacements toward specific places such as Retiro, Valcheta, and Choele Choel. Some of these places are also mentioned by other sources, such as the memoirs of Salesian priests, the diaries of the region's new inhabitants, and military reports. People were concentrated, for example, at Castro Fort ${ }^{12}$ by February 1884, at Chichinales ${ }^{13}$ beginning in 1885 , and at Valcheta ${ }^{44}$-all in what is now the province of Río Negro. ${ }^{15}$ There were also, according to Father Milanesio, more than 20,000 Indians concentrated near the Andes, in the current province of Neuquen. ${ }^{16}$ 
The way the prisoners were treated, and especially the dismembering of families, was a subject of scandal in those days. At the National Congress in 1884, Senator Aristóbulo del Valle stated,

\begin{abstract}
We have taken families from the savages, we have brought them to this center of civilization, where every right seems to be guaranteed, and yet we have not respected for these families any of the rights that belong, not only to civilized men, but to humanity: we have enslaved the men, prostituted the women, we have torn the children away from their mothers, we have sent old men to work as slaves anywhere. In a word, we have turned our backs and broken all the laws that govern the moral actions of men.
\end{abstract}

Del Valle denounced the fact that every new carnpaign turned women and children into the spoils of war, and he accused the public opinion of complicity. ${ }^{17}$

At the same time, the press periodically reminded the public of the miserable living conditions of the subjugated. A Buenos Aires newspaper described their disgraceful journey:

Here come the Indian prisoners with their families, most of whom were marched here or carried on carts. The desperation, the crying does not stop, children are taken away from their mothers because they are given away as presents in their presence, despite the cries, the screams and the begging that, with their arms aiming at the sky, these Indian women shout. In that human scenery, the Indian men cover their faces, some look down hopelessly, the mother holds her child against her breast, the Indian father steps in front, in despair to protect his family from the progress of civilization. ${ }^{18}$

One concentration camp frequently mentioned by the survivors' descendents is Martín García Island, which at least since 1872 was used for the gathering and distribution of Indigenous prisoners. This island, located in the middle of the River Plate, was used as a prison (not only for Indigenous people) until the mid-twentieth century. According to information from official files, it was in 1879 that the major influx of Indigenous prisoners arrived. 19

The elevated death rate, as well as a variety of illnesses suffered by the Natives who were deported to the island, account for physical and mental harm as well as degrading living conditions. It is important to underline that these prisoners were transferred to the island not as criminals-as many other prisoners were-but as "Indigenous people." It was their social condition, and not any individual reason, that led to their imprisonment.

The deportees were, in many cases, families. Once on the island, they were separated and catalogued according to their sex, age, working capacity, and military competence. ${ }^{20}$

Parish records are an invaluable source in studying Martín García Island because they include the personal identities of those who were concentrated there or sent to their final destination. For example, from the baptismal records we can deduce that more than 800 Indigenous persons were baptized on the island between January and November 1879. Most of them came from Pampa and Patagonia, and others from Chaco. ${ }^{21}$ Most of the baptisms were performed in articulo mortis (at the point of death). The death records show that at least 234 Indigenous prisoners died of smallpox in less than five months. In October 1878, the island's doctor warned the authorities about the condition of 148 newcomers: 
undoubtedly they come already infected ... heavy work would only weaken them ... they are weak because they are underfed, the sadness that they carry, the moral despondency, they feel the loss of the desert ... and besides the illnesses spreading, all of this suggests that they will be inoperative at work. ${ }^{22}$

The concentration, deportation, and redistribution policies were partly a response to the increasing requests for laborers by provincial elites. In the province of Tucumán, the excessive exploitation of the enslaved workforce, composed of Indians captured in the Pampas and Chaco, merited the intervention of a government bureaucrat in charge of the defense "of the poor and minors." 23 The provincial historical archives hold the record of the inspection of only one sugar refinery, El Colmenar. ${ }^{24}$ This inspection documented that Engineer Colombres suggested that he did not know the statutory contract and therefore he did not pay the workers or give them food or dress them properly; that through the translators the inspector learned that most of the Indigenous workers had run away, ${ }^{25}$ especially the men; that smallpox had killed the rest; that some workers were ill during the inspection; and that women had been beaten up, and at least one of them had died as a result. The inspector observes that the Indian women were dressed "in the outfit they wore in their huts." Not only had the businessman failed to fulfill his duty, the inspector's report also suggests that the forced redistribution of Indians was failing to cover its vaunted "civilizatory" aim"26 (see section (c) below).

This episode suggests at least three things. First, there existed a certain, though erratic, governmental will to regulate and inspect the Indian prisoners' working conditions. Second, the lack of official communication of the regulations implied the naturalization of slave treatment. Third, although the inspectors announced further inspections, these were not carried out; nor was there any official response to these reports. ${ }^{27}$

\section{(c) Deliberately Inflicting on the Group Conditions of Life Calculated to Bring About Its Physical Destruction in Whole or in Part}

The deportations created conditions of exile and overcrowding in hostile and unknown territory, under newly imposed practices and unsanitary conditions that put deportees at high risk of death from infectious disease. Thus, in addition to practices that severely harmed the physical and mental integrity of the Natives, relocation and concentration also condernned them to probable physical destruction.

Simultaneously, the Indigenous concentration camps of the late nineteenth century aimed to discipline and "prepare" those who were supposed to become part of "civilization," as well as to send an effective message of totalitarian discipline to society as a whole. ${ }^{28}$ The conception of the Indigenous population as worthy of condemnation to forced labor followed from their being driven into a state of exception derived from the genocidal plan. This process drew a line between the Indigenous population and the immigrant population, who did not share the same status. The exceptionality of the Natives may even be understood as a disciplinary practice for the immigrants. Nonetheless, our hypothesis is that the inhuman exploitation conditions, the trauma of war and expropriation, defeat, exile, the division of families, and the loss of social and cultural referents caused a much larger number of deaths than the war itself.

On 29 October 1885, the newspaper La Razón asked, "How many of the Indians distributed are left in the sugar refineries? Almost none ... Long and sad stories 
were told in reference to the Indians that stood among us, until the disappearance of all of them has finished their mourning." 29

Finally, the population that remained in Pampa and Patagonia after the military campaigns of 1878-1885 suffered continual instability with respect to access to the land. The communities that persisted after the campaigns were spatially scattered and surrounded by growing privatized spaces (see Part 2 below). The ban on access to land, combined, up to the present day, with the Indigenous populations' condition as non-qualified rural laborers, ensured the unlimited enrichment of ranchers and landowners.

\section{(d) Imposing Measures Intended to Prevent Births within the Group}

Policies aimed at limiting reproduction within Indigenous groups are evident through several practices. Although some groups within the Catholic Church actively resisted the division of families, the military agency encouraged the separation of men, women, and children as a moral and tactical means of dissuasion and repression. Thus, the army's first action following the imprisonment of Indigenous groups was to classify and separate the captured persons. Sometimes, some of those persons met again at their destinations, but most never heard of one another again.

Even accepting that gender-based separation was a disciplinary measure, it is important to contextualize the governing generation within the trend of political thought at the end of the century toward social Darwinism and eugemics. There are numerous testimonies on this matter. In previous decades, Charles Darwin had mentioned, in his memoir of his trip through Pampa and Patagonia, that the soldiers of Governor Rosas would rather kill young Indian women because "they have many children." 30 National congressman Manuel Cabral provoked a scandal in 1900 when he stated that "we should take people to mix the Indigenous people and bring to an end the primitive race... what we want is to suppress savage peoples from one generation to the next." 31

Cabral's formula leads us to a related subject: forced or induced marriage and its outcome of mixed races. ${ }^{32}$ Thanks to widespread imagery of white women captured by the Indians, the kidnapping of Indigenous women as trophies of war was concealed or justified as a necessity of war. Alfredo Ebelot, a famous engineer, expressed his disappointment in the lack of military professionalism demonstrated by the fact that Indigenous women and children "accompanied" "White" soldiers. Their presence distanced the National Army from the ideal of a "civilizatory" (European) army. ${ }^{33}$

Other witnesses, such as Commander Prado, disguised the rape of women as a legitimate choice:

After [the battle] Colonel Villegas told us: "This is the way I like it. You have behaved as soldiers of the 3rd [Company]. As a reward, you will have 48 hours of rest, and each one of you will receive a horse from the ones taken from the Indians. And regarding the Indian women, see which one wants to live with you." None of them refused..$^{34}$

Suffering division from family and community was a common destiny for those young men who were compelled to join the army or the navy during their reproductive years. To mention one example, in June 1879 General Roca, the minister of war, gave the order to "separate 150 Indians from the [Martin Garcia] Island to join the navy ... you should choose them young and healthy and therefore they should be checked on by a doctor." 35 


\title{
(e) Forcibly Transferring Children of the Group to Another Group
}

\begin{abstract}
"She used to tell me everything, she cried, then she started again, my grandmother... she was a girl when they took her. The first to come were those who took the children away." (Catalina Antilef, Futahuao, Chubut) ${ }^{36}$
\end{abstract}

The forced transfer of Indigenous children to different sectors of Argentinean society has been a constant, from the military campaigns, as a massive practice with respect to prisoners, until recently, in a far more dispersed but regular fashion.

By the late nineteenth century, there was a great demand for young women and children to work in domestic service for high-society families in Buenos Aires and other cities. For example, the army's General Inspection and Command received and delivered to Martín García Island numerous requests, such as "an Indigenous family with one woman and two children, a boy and a girl, to be destined to Mister Correctional Judge, Dr. Borres."37 Similarly, the island's chief, Donato Alvarez, placed three orders from President Avellaneda: "send three women between ten and twelve and a boy about the same age"; "from the Indians in deposit, eight girls and a boy, the strongest, should be sent. All these creatures ... healthy and strong," as well as a female Indian "about twenty years old with a young male child." 38

Claudia Salomín Tarquini points out that in 1891, a priest destined for La Pampa noticed the fear that the Natives felt when they were asked to summon their families. Some years before, such gatherings had been the opportunity to take children away from thei parents. When the Franciscan priests reached General Acha in La Pampa, they asked Linconao Cabral to assemble his people to baptize them:

He tried to do it, but he faced some difficulties; those who had to baptize their children feared that the godparents would take them away as it had happened in Sarmiento, years before, taken the children away, which had been a real barbarity. [A few days afterl ... we saw Major Linconao at the head of the Indians, at least 150 of them. It was deeply moving to see so many Indians, the same that years before had been everybody's terror, presenting themselves humble and peacefully, after they were sure that they would not have their beloved children taken away ... ${ }^{39}$

The kidnapping of children was a regular military practice, aimed at weakening the enemy's strategies. In 1878, La Nación described a tragic event when Colonel Olascoaga, "after taking some [Indian] children, let the Indians kill 30 national guards ... abandoning them to the Indians' outrage and revenge for finding themselves without their women and children." 40 This practice also served to fulfill the aristocratic pretensions of a large sector of civil society who put pressure on the military to get servants-a practice that, among certain social sectors, persists today.

Above all, however, it must be emphasized that the appropriation of children was justified as being for their own good, to take them away from savagery and favor their incorporation into the civilized world. Yet incorporation into "civilization" would not be enough to erase the stigma of having been born as Indigenous people.

In this sense, being an Indian child constituted an indelible mark that not only could not be overthrown, whatever one's efforts, but also determined, in many cases, a person's final, inhuman destiny. Patricia Arenas and Jorge Pinedo reconstruct the story of a young female member of the Ache people, Damiana.41 In 1896, when she was two, her parents' murderers took her and baptized her; at the age of four, she was handed over to work as a servant while she was studied by Dr. Lehmann- 
Nitsche, head of the Museum of La Plata. Because of her rebellious attitude, she was pathologized, criminalized, and sent to a madhouse. After she died of tuberculosis at the age of fourteen, her body was dissected, skinned, and divided in flasks and boxes, which were distributed between the museums of La Plata and Berlin. ${ }^{42}$

When groups and families were dismembered, individuals were assigned a "Christian" name, either by the Church or by the administrations of concentration camps. For example, the baptism records of Tucumán's parishes are full of Pampa children who were baptized between 1878 and 1879; while the names of the children are not mentioned, nor their parents', nor their places of origin, the names of their new "godparents" are. Despite a meticulous search, none of these records allowed the researchers to reconstruct a single lost identity. 43

Nowadays, a common topic in the Argentine press and in public opimion is the famine, extreme misery, and premature death in Indigenous communities, especially those in the north of the country. Argentine citizens agree that life for these people is extremely and unfairly tough. In general, it is concluded that those Indigenous groups that have not already disappeared will do so soon. However, it is less usual for the social drama be related to territorial expropriation and the social and cultural disintegration imposed on these peoples by the nation-state.

There is a double process of invisibilization at work, acting on both the history of those who have been the victims of genocide and the history of the nation-state as perpetrator.

\section{State Policies: Invisibility and Massacres over the Twentieth Century}

Genocide is completed and complemented at the same time by the hegemonic demal of diversity. Argentine indigenous policies-the hostile as well as the disciplinaryhave been grounded on the idea of Aboriginal extinction.

Nowadays, although there have been important steps forward in the field of human rights, influenced by the recent judgment of the perpetrators of the last military dictatorship, the state still denies the existence of genocide and the existence of crimes against humanity with respect to Indigenous peoples. In particular, in the legal process initiated as a result of the Napalpí massacre of 1924, the state refuses to acknowledge the Qom people as a specific ethnic group, thus precluding the possibility of recogaizing genocide-rolling back advances made on this terrain by civil organizations that support human rights. Moreover, the state's answer to the Qom's attorneys suggests that the possibility of treating the massacre as a crime against humanity has also been excluded. At the same time, the government promotes education programs to encourage inter-cultural and bilingual education and tolerance. ${ }^{44}$

This paradox is the result of the symbolic violence that began parallel to the constitution of the national state and its campaigns of military occupation in the late nineteenth century. Most of the initiatives in "favor" of "our Indigenous cultures" are built on the idea of physical extinction, turning these cultures into an addition of folklorized elements. Thus, when Indigenous peoples manifest a will to conduct their own destiny, repression is the norm.

In Part 1 we summarized some cases to sustain our thesis that the policies toward Indigenous peoples supported by the Argentine state during its process of consolidation constitute genocide. In addition, the Argentine elites legitimated these policies in such a way that the subjugation of the Natives and the consolidation of territorial sovereignty were not open to discussion. In this fashion, the descriptions, 
topics, and ideas of Natives created in that context have persisted in the Argentine imaginary, even among those who criticize the historical process of subjugation. In this section, therefore, we will analyze the mechanism that enabled a vast majority of the population to incorporate these concepts and descriptions as part of an irrevocable "common sense."

Through the concept of symbolic realization, the analysis can also be extended to the discourse sphere, that is, to ways of talking about this process. 45 This enables us to (1) shed light on the historic and actual consequences of a genocidal policy, (2) deconstruct the historical process as part of a "natural" evolution and progress of the Argentine national state, and (3) document how the success of the symbolic realization in the Argentinean case allows the continuity of concrete and material policies to the detriment of Indigenous populations (e.g., eviction of communities, expropriation of ancestral lands, legal resolutions that deny the (pre-)existence of the Indigenous communities) by state and private actors.

One of the key elements of the symbolic realization was, and still is, the education system-consolidated in 1884 by Law 1420. ${ }^{46}$ Despite changes in plans and methodologies over more than 120 years, the system still constructs an image of Argentina as a white and European nation.

In 2006, when the Nucleos de Aprendizaje Prioritario, or NAP (the basic learning elements and programs that every national primary and secondary school must provide) were renewed, the Ministry of Education, Science, and Technology launched as a main priority the need to encourage awareness of cultural diversity "with an inter-cultural point of view that privileges words and space for Indigenous knowledge, values, and cultural production." 47 However, a quick analysis of the NAP shows that the Indigenous peoples are confined to the past. In "Societies Through Time," the chapter that approaches the historical process of the Spanish conquest, the possibility of studying Indigenous peoples across time is mentioned only in a footnote. When NAP documents refer to the nineteenth century, they deal with national organization and the economic system but make no reference to Indigenous peoples. In this way, the NAP reproduces the idea that Indigenous peoples belong to the past or are long extinct. In other words, the NAP does not seem to have modified the idea that the Indigenous peoples are the "ancient Argentineans," displaced first by a colonial society and then by the massive arrival of European immigrants by the late nineteenth century, and have nothing to do with present times.

The education system, then, has provided a narrative of the Indigenous peoples as if they belonged to a chronological pre-history and so did their relation with the state. The narrative shows not a genocidal process but a "natural" development of history in which the immigrants "naturally" replace this "prehistoric" population. In this sense, there is a second mechanism of symbolic realization: the myth of an immigrant/white nation. The main topic in this nanative Argentinean history is the immigrant experience and the social and economic changes, and even crises, that relate to the immigrant:

Between the final years of the [eighteen-]seventies and the beginning of the eighties, the occupation of the "desert" became a fact, Buenos Aires was federalized, European immigration was encouraged ... the limited population of our country by the late nineteenth century was a limit to economic growth, as it could not provide a sufficient workforce. The arrival of immigrants sorted out this problem. ${ }^{48}$

There is not a single mention of the Indigenous inhabitants, a social subject that has disappeared from the textbooks forever. The Indigenous population is either expelled 
or exterminated. The capitalist development of Argentina becomes the great narrative, the "official history," and the destiny of the Natives is set aside. Neither their role as forced laborers nor as part of the army is exposed. This is where the functional topics of extermination and assimilation are grounded.

On the one hand, the extermination of almost every Native is reproduced even in the discourse of those sectors that consider the "Conquest of the Desert" as genocide; this is also part of the discourse of those who believe that nowadays there are no Indigenous peoples in Argentina. On the other hand, the idea of assimilation-that is, understanding the Natives as peasants, soldiers, national citizens-isolates the process by which the Natives are drawn to this situation.

Part of the mechanism of symbolic realization is the categorization of some Indigenous peoples-precisely those who retain the best levels of physical and cultural vitality and reproduction rates-as essentially "foreigners." An example is the Mapuche people, who have historically dwelled on both sides of the Andes, today divided between Chile and Argentina. The perception of the Mapuche people as foreigners was a product of the political discourse of the nineteenth century and was used to legitimate the military campaigns. ${ }^{49}$ The same assertion of foreignness is used today to deny land rights to Indigenous people in Patagonia: since the "true Indians" of Patagonia are "known" to be extinct, Indigenous claimants are assumed to be either liars or foreigners, which means they have no right to these lands.

While the official education system has succeeded in cementing the idea of Indigenous peoples' being relegated to the past, to extinction, or to a folklorized essence, the images accompanying this process have reaffirmed these arguments. For example, after the military campaigns of the nineteenth century, a painting was commissioned from Juan Manuel Blanes, an Uruguayan artist, to celebrate the heroic event. This painting eventually became the image that springs to any Argentine citizen's mind in connection with the "Conquest of the Desert." In every successive reproduction of the painting, even that on the 100-peso bill, the image has been cropped further, leaving the army in the center and dehberately excluding: the Indigenous people.

These mechanisms of invisibilization, together with a discourse of national homogeneity, had different effects on survivors of the genocide. For those who managed to establish a collective strategy-for instance, regrouping around a chief who had some capacity to deal with the state to request lands-a condition of maintaining that collective was the adoption of the dominant culture and language. 50 For those who did not get any land from the state, the process of invisibilization was assumed as a strategy-especially from one generation to the next-to avoid discrimination. This process, both imposed and assumed, became worst when land began to be expropriated and fenced. The advance of private property across the twentieth century caused a migratory flux from the fields toward the cities. Along this trajectory the Indigenous population swelled the marginal populations of urban areas, experiencing a new fragmentation and deepening the concealment of their identity.

We must wonder, then, whether every state practice toward the Indigenous population may be considered genocidal, or whether many practices now operating on the subaltern are grounded in genocidal practices, in the context of modernity. In the case of Indigenous peoples, there exists a series of material mechanisms that cannot be considered specifically genocidal but are nonetheless a product of the relations in place from the genocide onward. That is, some of the practices performed by the state, the ways in which it has institutionalized its relations with the Natives, 
and, at the same time, the manner in which the latter struggle with, deal with, or make demands against the state's hegemonic practices, are all a product of genocide. The genocide outlines the social spaces that may be occupied by Argentinean society as a whole. 51

Therefore, we cannot conceive of the Argentine state without the Indigenous genocide, and vice versa. And we can analyze neither the Argentine state's policy toward Indigenous communities nor current Indigenous peoples' agency without bearing these origins in mind. In this sense, throughout the twentieth century, even though a policy of "Indigenous assimilation" as part of the citizenry was announced, state policies continued to perceive Indigenous peoples as inferior, as an internal Other-once again anchored to the assumptions of extinction and assimilation. The state tried to discipline a population that, being already marked with exile and (material and symbolic) violence, was ever tuming into a potential threat. In fact, a double threat: as a real threat, should they react against the successive attacks (fueled by the imaginary of the savage), and also as a threat to the evidence of an alleged homogeneous nation.

In this sense, it is important to stress two forms of violence in the twentieth century: massacres and land expropriations.

In 1924, during the presidency of Marcelo T. de Alvear (a leader of the UCR party), an Indigenous protest was suppressed by the police of the Chaco National Territory, resulting in the murder of more than 500 Toba and Mocovi people. The killing took place on the lands of Napalpí, a reserve for Indigenous families that was considered a model. This reserve had been founded by the federal state thirteen years before, with the aim of incorporating the Natives into the capitalist production system as workers. ${ }^{52}$

The overcrowded, unhealthy, and exploitive conditions-working "from sunrise to sunset," as a survivor's daughter expresses it ${ }^{53}$-as well as the prohibition imposed by the provincial governor, Fermando Centeno, forbidding the Indigenous people to travel to the neighboring provinces of Salta and Jujuy in search of better jobs, the 15 percent discount on crops harvested by Natives, and the constant police persecution, generated a protest movement among the communities of the reserve. In response, the local ${ }^{54}$ and national press referred to the possibility of malones-raids-and to the existence of Indigenous murderers and "fanatical religious leaders." At the same time, the landowners and local businessmen put pressure on Governor Centeno to bring the confict to an end.

On 19 July, at 9:00 a.m., 130 policemen and an airplane from the Chaco Airclub fired from land and air on the Indigenous people who gathered in Napalpi's central square; the survivors were hunted down during the days that followed. The leaders' corpses were displayed in a public square in the nearby town of Quitilipi; the rest of the dead, estimated at over 500, were burned, then buried in common graves.

In October 1947, during the government of Juan D. Perón, another event took place that has been silenced through generations and only recently returned to daylight, since a federal judge is now investigating it under the legal rubric of genocide. At that time, massive layoffs in the sugar refineries of the Argentinean northwest resulted in famine among the communities of the Chaco region. Since their lands had been expropriated, the chaquense communities sold their labor to the sugarcane harvest. In Las Lomitas, in the west of the province of Formosa, thousands of Indigenous people gathered around a charismatic priest/healer and a 
traditional chief. Although the meeting was peaceful-the Pilagá people only prayed and foraged for food-the Argentinean criollos' paranoia dictated that the dispersion and the silencing of the Pilagá became a state affair. The federal government sent the gendarmerie, who shot and bombarded the demonstrators, chasing the survivors through the jungle for more a month and causing the death of a significant proportion of the Pilagá people-estimates of the numbers range from 800 to 2,000 dead. ${ }^{50}$

After the brutal repression suffered by the Pilagá in Las Lomitas, the gendarmerie imprisoned some of the survivors who were trying to escape to Paraguay and transferred them to a state colony in Formosa called Francisco Muñiz. There they were forced to cut wood for the state-owned sawmill and to sow rice, receiving no rewards from the harvest. Their living conditions were miserable, and, in addition, the children were separated from their families and sent to a religious institution. ${ }^{56}$ After several years the state sent a doctor to inspect the Muñiz colony; be certified that the colony's worst problem was famine. ${ }^{57}$

These are just two cases of physical violence by military/police personnel against Indigenous peoples. Today, the narratives of similar cases is repeated across interethric frontiers. In every case, however, discovering the facts is arduous, as pain and fear nurture the silence, even now, of the survivors of genocide, their descendants, and the witnesses.

The three types of expropriation that are mentioned below acknowledge the continuity and diversity of expulsion mechanisms accomplished by individualsmerchants and businessmen-and large land companies. These agents took advantage of the legal vulnerability in which most Indigenous families were living and extended their fences over their fields. In numerous cases, state bureaucrats responsible for protecting Indigenous families have allied with individuals to evict those families from their lands, as in the present case of the Mariano Epulef community in Río Negro. ${ }^{58}$

Such actions have worsened during recent years. In the province of Chaco, expropriation by private enterprises has modified property maps; according to the provincial statistics, 3,500,000 hectares of public land in 1994 became 650,000 hectares by December 2007. It is important to underline the fact that the Indigenous communities have no property deeds and, in most cases, live on the few public hectares that are left.

A second mechanism of expropriation are evictions promoted by the state under the banner of "inconvenience," as for example in the so-called Boquete Nabuelpan, in the province of Chubut, in 1937. In this case, a community to whom the state had granted lands in 1908 was evicted in favor of more influential members of society, who allegedly had better farming skills. The Indigenous people were, in this case, labeled "Chilean Indians" and were accused of continuing to lead a life of "savagery." 59

But such evictions are also produced as an outcome of the duality of the state. Such was the case of the Toba (Qom) colony of La Primavera in Formosa. During the 1980s, the province granted 5,000 hectares to the Qom, but the federal government continued to distribute public land to private owners-including lands within the colony. Many Indigenous members of the colony were evicted from their lands.

The third mechanism is related to the quality and quantity of the lands that are eventually conceded to Indigenous communities. Their low productivity imposes limits on the people's means of production as well as on their own reproduction and continuity in the land. 
The lands given to Indigenous peoples have geographical and political limits defined by the state that do not respect the productive and cultural needs of the communities - for instance, places for hunting, fishing, and gathering food, or sacred places. In general, they are low-priced lands that nonetheless can be expropriated according to the needs of the market. In fact, the new monoculture economy, based on small workforce needs and extensive soil exploitation, is once again moving the agricultural frontier. Simultaneously, there is a growing number of relocations and evictions of Indigenous communities that yet does not seem to scandalize Argentina's citizens.

\section{The Concept of Genocide and the Questioning of the State-Society Relationship}

Despite the fact that in the past the academic and juridical communities strongly rejected considering the use of the term "genocide" to refer to Argentine policies toward Indigenous peoples, we can now observe that its use, still full of prejudices, has become widespread. On the one hand, this is the outcome of a leading tendency in international agreements, forums, and documents to condemn the exploitation and subordination suffered by Indigenous peoples in the present. On the other hand, in the local/national arena, it is part of the critical revision of the relationship between state and society that began with the dernocratic era after the last dictatorship, and results particularly from the struggle of human-rights organizations and Indigenous activists to legitimate Native demands as part of the human-rights agenda. However, there is still a significant gap between acknowledgement and "visibility," on the one hand, and, on the other, the profound historical revision that would bring up for debate the historical processes that produced the conditions of possibility for a "Inarginal citizenship" to exist.

Since the socio-economic situation of the Indigenous peoples has been brought to light, the duty to do something about it has been discussed by different agencies and political projects. The idea of society's "moral duty" to the Indigenous population constitutes a debatable ground in which the use of the term "genocide" has central importance. The term enables us to think about the idea of "reparations" and, in connection with this, about the questions "who?" "what?" and "what for?"

The arena in which these discussions take place is constituted, first, by the questioning of the historiographic narrative inscribed in the daily geography of Argentina's citizens (the naming of streets, cities, squares, and statues that celebrate battles, national heroes, and governors associated either with authoritarian regimes or with the oligarchic power constituted by 1880). The "Official history" is identified as the matrix of validation of the crimes against humanity perpetrated during the last dictatorship (1976-1983). The debate on this recent history has fuelled the discussion of the term "genocide." In addition, discussion of the historical research behind that "official history" led to some other social practices' being named genocidal, among them the subjugation and forced incorporation of Native populations into the nation-state. The debate on monuments and street naming-especially as a consequence of the writer Osvaldo Bayer's public campaign-aims to shed light on the different disciplinary mechanisms imposed on the subaltern classes, many of which originated in the same regime that undertook the Conquest of the Desert. Thus, in this matrix, immigrants, Indigenous peoples, and working class are part of the same group of "victims" of the oligarchic capitalist order. ${ }^{60}$ 
Second, emerging from some teachers' unions and associations, there is an important reaction against the NAP-mentioned in Part 2-and its exclusion of Native peoples' history from the national history. In this way, these teachers are trying to make visible what it is still absent from the books they have to work with at school.

Third, there have been specific initiatives of solidarity with Indigenous peoples, such as the legal actions taken against the state by groups of lawyers on the cases of the massacres at Napalpi (1924) and La Bomba (1947). The Napalpí Massacre, in particular, has achieved the status of an "epitomizing event"; 61 that is, it has become part of a public discussion as the concretion of genocide itself. The risk is, then, that in this case, as well as in the debate surrounding the Roca statues, the debate could potentially close down to an understanding that Napalpi is "the" genocide and that Roca is "the" perpetrator of genocide. Such an outcome would put at risk the main learning that these massacres bring to the present: that they should be inscribed in a major context of nation-building where genocide has been reproduced in history regardless of the political parties in charge of the administration. As an example, the massacres of Napalpí and La Bomba were executed during "popular" and democratic regimes led by different political parties. ${ }^{62}$

Fourth, within academia there is discussion of the applicability of the concept of genocide. On the one hand, this is the outcome of in-depth research on the historical processes that led to the constitution of the national state, and especially of its disciplinary mechanisms, which disproved the argument that there had been no specific state policy with respect to the Indigenous population. On the other hand, there has been an increase in theoretical and nethodological debates that enable us to reflect on the concept of genocide in different contexts and periods. Finally, there has been an important process of revision with respect to academic practice, institutional history, and the constitution of academic disciplines. In particular, the handling of "anthropological collections" has been questioned, 63 as has the unauthorized fieldwork carried out by archeologists and anthropologists in Indigenous communities and the omission of Indigenous history as a subject of study by historians.

Finally, and most importantly, certain inner sectors of Indigenous peoples have, in the last decade, found in the concept of genocide a representative manner of making demands on the state and society. The majority of Indigenous claims and politics have in common a questioning of the historical process of subjugation, because their demands are not delimited within a present conflict but are the accumulation of successive conflicts in their relations with the state. ${ }^{64}$

To date, a social and discursive movement has been working toward the installation of the concept of genocide and the need to revise the hegemonic historiography; at the sanie time, it has generated a backlash from a set of different actors, however coincident in their arguments. Denial-those who minimize or neglect the social practices described in Part 1-argue the extemporaneousness of the concept of genocide, or of concentration camps or of crimes against humanity, and label the supporters of this "other" history unscientific and proof-less or supportive of "dark" interests or agents (Marxist-Leninists, terrorists, foreigners, romantics, traitors, political agitators, and so on).

Thus, different sectors have reacted to the possibility of accepting the idea of genocide. Although ready to accept that there have been "some mistakes" in the past, they consider that throughout history there have been plenty of such excesses and that no particular social group should present itself as having more right 
to change what is now a "collective patrimony." Thus, proposals to widen our knowledge of our national history are refused in order to sustain a local/national identity.

Finally, as part of this reaction, the concept of genocide has also been incorporated within projects of political integration. In this way, the state-federal or provincialthrough its different agencies and offices, has begun to incorporate the use of the term. The state becomes then self-referent as defender of the victims of genocide while emptying the identity of the perpetrator. Indigenous peoples, according to this position, may have been victims of genocide, but the current state bears no responsibility.

\section{From Genocide to Reparation}

The concept of genocide has embedded not only the acknowledgment and the acceptance of a multicultural country but also the idea of "reparation," in both material and symbolic terms. This brings on another discussion about how to understand this "reparation," because what seems to be the answer to the problem for some actors means the continuity of the "genocide" for others.

To date, politicians' projects, whether national or provincial, have tried to contain the margins of this possible reparation (using various terms). On the one hand, some sustain the idea of a total extermination and consequently depoliticize the process and the demands. They incorporate the idea of genocide to argue that there are no Indigenous persons left, only mixed-bloods and descendants; therefore "material reparation" is impracticable and, in any case, "unfair" and "arbitrary."

On the other hand, and in consonance with international changes in discourse, the acknowledgraent through the constitutional reform of 1994 of the Natives as "Indigenous peoples" (pre-existing the formation of the state) has been a first symbolic reparation, intended to show how modern and respectful the national society has become. Nonetheless, this "restitution" has collided with the demands of Indigenous activists, who visualize culturally diverse collective subjects with their own voices and agendas and assert that there has not yet been a real restitution that answers their own needs and interests.

This is the basis on which debates and differences are disputed among public agencies, NGOs, and Indigenous orgamizations. In particular, both public agencies and NGOs begin with the idea of a "common solution" for Indigenous peoples throughout the country, bearing in mind a "common interest." The Indigenous organizations, on the other hand, argue that it is not possible to come to a solution within the same state logic of "making the differences homogeneous," because the diverse historical processes by which the various peoples have been led to a homogeneous status of marginal and subaltern citizenship must be taken into consideration.

In other words, the problem consists of establishing who defines what and, especially, what for. Regardless of the terms we choose to describe the process (genocide, respect, reparation, etc.), what is really at stake is the what for. At least, many Indigenous organizations maintain that the what for still bears the same aim: to facilitate and optimize the mechanisms of domination and expropriation that, under the so-called cormmunity of interests, settle the ethnic and class asymmetry into a determined social order. 


\section{Reparation as Restitution of Citizenship}

The acknowledgment of multiculturalism and the openness toward diversity in the last two decades have built and established social places of detention where individuals set, through active practices, bonds and senses of belonging. ${ }^{65}$ At the same time, they have found limits in the official policies that try to determine their welfare. Today, the concept of genocide is the subject of discussion, although as yet it is strongly resisted as a concept of historical description. In this way, for example, when the National Institute Against Discrimination (INADI) reacted against various expressions of negationism, it passed on a law project to condemo expressions of demial or minimization of the Holocaust, the Armeman Genocide, and the genocide by Argentina's last dictatorship but did not even mention the Indigenous genocide. ${ }^{66}$

At the same time, during a school inauguration in Santa Victoria Este-a location in northwest Argentina with a vast Indigenous population---President Cristina Fernández said, "I ask forgiveness of the Indigenous peoples for the underhand discrimination hidden behind our state's inaction," 67 and named the place the "backyard of the country's backyard." The government ceremony was intended to bring closer to a regular citizenship people who have been apparently forgotten by the nation-state in its welfare gifts. However, active state practices that have damaged them for over a century were not mentioned.

Reparation, conceived as "reparation from marginal citizenship," lies far from an acknowledgment of autonomy and of double citizenship. Its aim is, again, to "give back the condition of equals," rendering inner differences invisible in order to make visible the citizen's equality-that is, fixing "one" damaged social body. This is the context in which, since 1983, Indigenous rights have become part of the accusations against state violence. However, each time the idea of a separate-or, at least, a more complex and juxtaposed-social body is proposed, similar reactions and mechanisms of denial arise, pushing to reinstate a homogeneous, hegemonic, and discrete model of citizenship.

\section{Final Words}

The debate around the concept of genocide relating to Argentina's Indigenous policy has enabled a new arena for debate, where new questions arise. It allows us to think about whether new changes in the relationships of subaltemity can be researched and to question what has changed or has continued in the structure of power, and in its material and symbolic conditions, around the construction of policies and practices promoted "by" and "for" Indigenous peoples.

Motivated by these questions, however, it is important to acknowledge what this process has caused. First, something has begun to change, in that the idea that the Indians'-now "Indigenous peoples"'-extinction has ceased to be a hegemonic assertion. At least there is a necessity to explain what has actually happened. It may be interpreted either as genocide or through different theoretical answers (e.g., the idea of assimilation and mixing), but now in a context in which the faces of real Indigenous persons have gained presence in the political and public arena. In other words, "General Roca's defenders" must now face the fact that there are Indigenous witnesses and professionals who will contradict their defense.

Second, when using the term "genocide," there is still the challenge of inscribing it in a wider process related to the construction of a certain social order. That is, there is a tendency to replace the term "massacre" or "excess" with the term "genocide" in reference to events of the past, detaching it from its consequences 
in the present as an already-overcome historical period. But if we understand that the social practices carried out against the Indigenous population that we have described here-concentration camps, the separation of families, deportations, killings, massacres, forced labor, redistribution of children, material expropriations, and so on-constituted a genocide, we should also shed light on the fact that these events were not denounced before and ask why they are still so extremely difficult for Argentinean society to accept.

The imposed social order has evidently been "successful," and therefore the "consequences" of the genocide have become constitutive of the society in which we hive. Thus, we need to ask ourselves what has changed, and what has not, in the historiography and in its questioning of the foundations of the state.

Finally, and as long as we are both scholars and also part of civil society, we would like to open the question around the changes that could have been produced in the struggle to control hegemony of representations and self-representations. Have the criteria for authority changed? Is there any openness toward "new public voices"? Who can cast the first word?

\section{Notes}

1. The former of these campaigns is known officially and popularly as "the Conquest of the Desert," and it epitomizes this process from the point of view of the average citizen. Thus, many of our examples will be taken from this campaign, although it was neither the first nor the last such military operation.

2. The project is titled "Memories and Files of the Genocide: Subjugation and Incorporation of Indigenous Peoples to the Nation-State" and is supported by the University of Buenos Aires. This project is part of the Red de Investigadores sobre Genocidio en la Política Indígena Argentina.

3. Walter Delrio, Diana Lenton, Marcelo Musante, Mariano Nagy, Alexis Papazian, and Gerardo Raschcovsky, "Reflexiones sobre Ia dinámica genocida en la relación del Estado argentino con los pueblos originarios" (Paper presented at Segundo Encuentro Internacional Análisis de las Prácticas Sociales Genocidas, Buenos Aires, November 2007).

4. Convention on the Prevention and Punishment of the Crime of Genocide, 9 December 1948, 78 U.N.T.S. 277, http//www2.ohchr.org/englishlaw/genocide.htm (accessed 15 June 2010), art. 2.

5. Julio A. Roca, presidential speech before the Legislative Assembly, 6 May 1884 (National Congress, daily report on sessions). Unless otherwise noted, all translations into English are our own.

6. Giorgio Agamben, Estado de Excepción. Homo sacer II, trans. Antomo Gimeno Cuspinera (Valencia: Pre-Textos Editorial, 2003)

7. Diana Lenton, "De centauros a protegidos, La construcción del sujeto de la política indigenista Argentina desde los debates parlamentarios (1880-1970)" (PhD diss., Universidad de Buenos Aires, 2005).

8. In Spanish, "crimen de lesa humanidad." La Nación 16-17 November 1878; see Lenton, "De centauros a protegidos."

9. Interview by Ana Ramos and Walter Delrio, February 2006, translated by the authors.

10. A description of these events is narrated in Luis Jorge Fontana, Viaje de Exploracion en la Patagonia Austral (Buenos Aires: Talleres de la Tribuna Nacional, 1886).

11. Mixed-blood, Creole, or European descendants born in America.

12. At least 300 persons from the Sacamata and Pichaleo tribes were concentrated in this place. José Garofoli, Datos Biogrúficos and Excursiones del P. Milanesio, Archivo Salesiano Inspectoría de Buenos Aires (Salesian central archive of Buenos Aires) [ASTBA], Indígenas $201.2,74$. 
13. By 1886 more than 1,000 persons were concentrated when the Salesians Cagliero, Remotti, and Panaro visited the Nancuche and Sayhueque tribes' prisoners in this location. Garofoli, Datos Biográficos, 169; ASIBA, Indígenas C.201.4, doc. 60.

14. Valcheta is one of the most significant cases, both because of the number of people concentrated and because of the numerous references related to it through the mapuchetehuelche narratives in Patagonia. Valcheta is named as a place of concentration, torture, and death. John Daniel Evans, a Welsh settler, mentioned it as a concentration center. Clery A. Evans, John Daniel Evans, El Molinero: Una historia entre galeses y la Colonia 16 de Octubre (Trevelin: Impresiones Lahuan, 1994), 92-93.

15. Pilar Pérez, "Represión y resistencia: una aproximación a los campos de concentración en el territorio patagónico a fines del siglo XIX" (Paper presented at II Encuentro Internacional Análisis de las Prácticas Sociales Genocidas, Universidad Tres de Febrero, Buenos Aires, 2007).

16. Pedro Giacomini, Misiones de la Patagonia, ASIBA, 99.

17. National Congress, Daily Report on Sessions, 19 August 1884 [in Spanish].

18. El Nacional, 21 January 1879.

19. These conclusions are drawn from an analysis of various sources found in the Archivo General de la Armada (arny general archives) [AGA], the Archivo de la Arquidiócesis de Buenos Aires (the archives of the Archdiocese of Buenos Aires) [ABAA], and the Archivo General de la Nación (national general archives) [NGA]; see Mariano Nagy and Alexis Papazian, "De la Isla como Campo. Prácticas de disciplinamiento indigena en la Isla Martín García hacia fines s. XXX" (Paper presented at XII Jomadas InterescuelasDepartamentos de Historia, Universidad del Comahue, Bariloche. 2009).

20. AGA, boxes 15272-15287.

21. ABAA, Books 1-3 of Baptism Acts and Book 1 of Death Acts, Martín Garcia's Chapel, January-May 1879; AGA, boxes 15277, 15278, and 15280 .

22. AGA, box 15278, Savino O'Donnell, Surgeon of the Island, 12 October 1878. The doctor's warnings were given one month before a deadly outbreak of smallpox.

23. Who also assumed responsibility for Indigenous people after the presidential decree of 3 May 1899. Lenton, "De centauros a protegidos."

24. Enrique Hugo Mases, Estado y cuestión indígena. El destino final de los indios sometidos en el fin del territorio (1878-1910) (Buenos Aires: Prometeo libros/Entrepasados, 2002); Eduardo Rosenzvaig, Historia Social de Tucumán y del azúcar, vol. 2: El Ingenio (San Miguel de Tucumán: Universidad Nacional de Tucumán, 1986); Diana Lenton and Jorge Sosa, "La expatriación de los pampas y su incorporación forzada en la sociedad tucumana de finales del siglo XIX" (Paper presented at Jornadas de Estudios Indígenas y Coloniales, Unjversidad de Jujuy, San Salvador de Jujuy, Argentina, November 2009).

25. The press reported sporadic escapes from the sugar plantations. For example, the newspaper El Argentino reported that "almost every Indian has run away" from El Colmenar; some days later, the same newspaper stated that "we should be aware of the Indians if they are kept in huuger." El Argentino, 28 January 1879; Lenton and Sosa, "La expatriación de los pampas."

26. Archivo Histórico de la Provincia de Tucumán (AHT), Letter from Francisco del Corro and Evaristo Barrenechea to the Minister of Government, 10 February 1879.

27. Lenton and Sosa, "La expatriación de los parnpas."

28. Walter Delrio, Memorias de expropiación. Sometimiento e incorporación indigena en la Patagonia (1872-1943) (Bernal: Editorial de la Universidad Nacional de Quilmes, 2005); Lenton, "De centauros a protegidos."

29. Lenton and Sosa, "La expatriación de los pampas." The policy of dismembering families and using forced labor continued into the twentieth century, legitimated by rootives of "national interest" as well as by the defense of "civilized society." Among the first exanples is the overexploitation of the Kolla farmers in northwestern Argentina. Up to the middle of the twentieth century, the Kolla had their land expropriated and were compelled to undergo a process of proletarianization in the sugar refineries where 
Patagonian families had previously been. This practice was justified as "the only way to support a national industry in difficult regions."

30. Charles Darwin, Un naturalista en el Plata (1845), trans. Constantino Piquer (Buenos Aires: CEAL, 1978), 64.

31. National Congress, Daily Report on Sessions, 1 April 1900.

32. Lenton, "De centauros a protegidos."

33. Alfiedo Ebelot, La pampa. Costumbres argentinas (1890; reprint, Buenos Aires: Ed. Nueva Dimensión Argentina, 2001).

34. Manuel Prado, La guerra al malón (1907; reprint, Buenos Aires: EUDEBA, 1960), 95.

35. AGA, box 15279, 6 March 1879.

36. Interview by Ana Ramos and Walter Delrio, February 2006.

37. AGA, box 15279, 14 February 1879.

38. AGA, box 15279, 27 March 1879.

39. Chronicle of the mission of Fathers Herrera and Quaranta, General Acha, June 1891, quoted in Claudia Salomón Tarquini, Indigenas y paisanos en la pampa. Subaliernización, ciclos migratorios, integración urbana (1870-1976) (PhD diss., Universidad Nacional del Centro de la Provincia de Buenos Aires, 2008).

40. La Nación, 17 November 1878.

41. Patricia Arenas and Jorge Pinedo, "Damiana vuelve a los suyos," Página 12, 20 Novem. ber 2005, http:/www.pagina12.com.ar/diario/suplementos/radar/9-2639-2005-11-24.htrnl (accessed 3 February 2010).

42. Miguel Añon Suarez, Patricio Hanison, and Fernando Pepe, ldentificación y restitución: Colecciones de restos humanos en el Museo de La Plata (La Plata: Editorial GUIAS, 2008).

43. Lenton and Sosa, "La expatriación de los pampas."

44. See Walter Delio and Diana Lenton, "¿Qué, para qujénes y según quiénes? Repara. ciones, restituciones y negaciones del genocidio en la política indígena del estado argentino" (Paper presented at Latin American Studies Association (LASA) 2009 Congress, Rio de Janeiro, 11-14 June 2009).

45. Daniel Feierstein, Seis estudios sobre genocidio. Análisis de las relaciones sociales: otredad, exclusión, exterminio (Buenos Aires: EUDEBA, 2000). The term "symbolic realization" refers to the rebuilding of a genocidal experience as if it were not such an experience. Thus, not only does it "close the possibility of returning to the existing social relations before the genocide" (ibid., 24), it also inhibits and renders suspect any Indigenous agency, and considers the performances of that agency illegitimate and even fictitious, under the hegemonic discourse that sustains the lack of Native peoples in Argentina.

46. National Law No. 1420 on Common Education, 1884, http//www.bnm,me.gov.ar/giga1/ normas/5421.pdf (accessed 23 June 2010). This legislation was the resuit of a pedagogical congress held in 1882.

47. Núcleos de Aprendizajes Prioritarios (NAP) EGB / Nivel Medio (Buenos Aires: Ministerio de Educación, 2006).

48. History UBA 2004 (entrance course for secondary schools), 11.

49. Axel Lazzari and Diana Lenton, "Araucanization, Nation: A Century Inscribing Indians in the Pampas," in Contemporary Perspectives on the Native Peoples of Pampa: Bergin Garvey Series in Anthropology, ed. Claudia Briones and J.L. Lanata, 33-46 (Westport, CT: Greenwood, 2002).

50. Delrio, Memorias de expropiación.

51. Lawreuce Grossberg, "Power and Daily Life," in We gotta get out of this place. Popular conservatism and postmodern culture, by Lawrence Grossberg, 89-111 (New York: Routledge, 1992); Lawrence Grossberg, "Entre consenso y hegemonía: Notas sobre la forma hegemónica de la política moderna," Tabula Rusa 2 (2004): 49-57.

52. See Nicolás Iñigo Carrera, La violencia como potencia económica: Chaco 1870-1940 (Buenos Aires: Centro Editor de America Latina, 1988); Edgardo Cordeu and Alejandra 
Siffredi, De la algarroba al algodón: movimientos milenaristas del Chaco Argentino (Buenos Aires: Juárez Editor, 1971); Hugo Trinchero, Los Dominios del Demonio. Civilización y Barbarie en las Fronteras de la Nación. El Chaco Central (Buenos Aires: EUDEBA, 2000).

53. Juan Chico and Mario Fernández, Napa'lpí, la voz de la sangre (Resistencia: Subsecretaría de Cultura de la Provincia del Chaco, 2008).

54. La Voz del Chaco, 19 May 1924: 'Press release by the Chief of Police: in the Napalpi reservation, about 500 Indians have gathered; they have not yet committed any crime but slaughtering neighbors' animals. They are in a hostile mood; they do not want to listen to the messengers sent to deal with them. They threaten those Indians that work and have not joined them. We have heard that there are about eighty Indians armed with Winchester arms and some others with similar weapons. The rest carry knives and lances. Their attitude makes us assume that they have wider goals, which we try to avoid. Therefore we have asked the government for backup, because we believe that they will back off if they face a stronger force. These Indians have been fueled by one called Machado who names himself as a God."

55. The Pilagá escape across the jungle assumed tragic proportions when families had to abandon the wounded, sick, or weak who could not keep on running, thus increasing the death toll. One witness reported that for many days they had to walk bent over because the bushes in that area are so low, and that it was difficult to silence children who cried, until they reached the timberline area and could once again run upright. The cruel persecution led families to be involuntarily dismembered, and, as many today regret, they could not even bury their dead. Valeria Mapelman (dir), Octubre Pilagá [documentary film] (Buenos Aires: DVCam, 2010).

56. Survivor testimonies indicate that these children "never appeared" and that "nobody knows what became of them." Mapelman, ibid.

57. Ibid.

58. Lorena Cañuqueo, Laura Kropff, and Pilar Pérez, "Un "ulmenche" en el territorio patagónico del siglo XX? el caso de Mariano Epulef" (Paper presented at 3ras Jornadas de Historia de la Patagonia, Universidad del Comahue, Bariloche, November 2008).

59. Walter Delrio, "Mecanismos de tribalización en la Patagonia. Desde la gran crisis al primer gobierno peronista," Memoria Americana. Cuadernos de Etnohistoria 13 (2006): 209-42; Claudia Briones and Diana Lenton, "Debates parlamentarios y nación: la construcción discursiva de la inclusión/exclusión de los indigenas," Actas de las III Jornadas de Lingüística Aborigen (1997): 303-18.

60. Following this idea, there is a proposal to remove General Roca's monument on the main avenue of Buenos Aires and to replace it with a monument in memory of a Native woman and an immigrant one, both considered victims of Roca's repressive administration.

61. G. Landsman and S. Ciborski, "Representation and Politics: Contesting Histories of the Iroquois," Cultural Anthropology 7 (1992): 425-47, quoted in Claudia Briones, La alteri. dad en el cuarto mundo. Una construcción antropológica de la diferencia (Buenos Aires: Ediciones del Sol, 1998), 108.

62. Indeed, the federal government has argued against considering these two events as genocidal because they occurred during when elected governments were in power, and such governments are supposed to look after the welfare of their citizens. For further information see Red de Investigadores en Genocidio y Política Indígena, Napalpi y Rincón Bomba: debates sobre el genocidio de los Pueblos Originarios y los límites de la Justicia (Buenos Aires: GEG, DVD Multimedia, 2008).

63. See Añon Suarez et al., Ydentificación y restitución, on the collections of the Museum of La Plata. On the influence of national paradigms over alleged academic objectivity see Delrio, Memorias de expropiación; Lazzari and Lenton, Araucanization, Nation.

64. Diana Lenton, "El 'aporte antropológico' en un caso de evaluación de 'daño cultural," (Paper presented at the VI Congreso Red Latinoamericana de Antropología Jurídica, Bogotá, November 2008); Marcelo Musante, "La construcción del territorio chaqueño 
como parte de un proceso genocida." La revista del CCC 5/6 (2009), http://www.centrocultural.coop/revista/articulo/111/ (accessed 21 September 2009).

65. Grossberg, "Power and Daily Life."

66. "This agency works to penalize those who deny, defend or trivialize the Holocaust, the Armenian Genocide, and state terrorism applied by the military dictatorship that devastated our country... With respect to the dynamics that the debate itself will have, criminologists, constitutional experts, human-rights professors, human-rights organizations, and the community orgamizations involved (Armenian and Jewish) are expected to take part in it." Tomás Forster, "EI INADI presenta un borrador para punir la negación del holocausto," Púgina 12, 1 March 2009.

67. Clarin, 3 March 2009. 